International Journal of

Environmental Research and

Public Health

ISSN 1660-4601

www.mdpi.com/journal/ijerph

Article

\title{
Arsenic Accumulation and Translocation in Mangrove (Aegiceras corniculatum L.) Grown in Arsenic Contaminated Soils
}

\section{Gui-Rong Wu ${ }^{1,2}$, Hua-Long Hong ${ }^{1}$ and Chong-Ling Yan ${ }^{1, *}$}

1 Key Laboratory of Ministry of Education for Coastal and Wetland Ecosystems, Xiamen University, Xiamen 361000, China; E-Mails: hzwgr510@163.com (G.R.W.) honghl.aries@gmail.com (H.L.H.)

2 College of Chemical and Biological Engineering, Hezhou University, Hezhou 542800, China

* Author to whom correspondence should be addressed; E-Mail: ycl@xmu.edu.cn;

Tel./Fax: +86-592-2880232.

Academic Editor: Ravi Naidu

Received: 5 May 2015 / Accepted: 19 June 2015 / Published: 26 June 2015

\begin{abstract}
Mangrove wetlands serve as both a sink and source for arsenic (As), as mangrove plants are able to uptake and accumulate As. The present study used pot experiments to evaluate As accumulation and translocation in mangrove (Aegiceras corniculatum L.) seedlings grown in As contaminated soils. Results indicated that $A$. corniculatum seedlings grew normally under As stress with minute growth inhibition and biomass reduction at different As treatment concentrations in a range of $0-150 \mathrm{mg} \cdot \mathrm{kg}^{-1}$. As concentrations in roots, stems and leaves were increased with increasing As treatment concentrations, but As accumulated mainly in roots, with accumulation rates of $74.54 \%-89.26 \%$ of the total As accumulation. In particular, relatively high bioconcentration factor $(\mathrm{BCF})$ in root $(2.12-1.79)$, low BCF in stem (0.44-0.14) and leaf (0.06-0.01), and thereby a low translocation factor (TF) in stem/root (0.21-0.08) and leaf/root (0.02-0.008) were observed. These results demonstrated that $A$. corniculatum is an As excluder with the innate capacity to tolerate As stress and root tissues may be employed as a bio-indicator of As in polluted sediments. Additionally, A. corniculatum is a potential candidate mangrove species for As phytostabilization in tropical and subtropical estuarine wetlands.
\end{abstract}

Keywords: arsenic; Aegiceras corniculatum L.; accumulation; translocation; phytostabilization 


\section{Introduction}

Arsenic (As) is a toxic environmental metalloid originating from geological and/or anthropogenic sources such as mining, burning of fossil fuels, use of fertilizers and agrochemicals, etc. $[1,2]$. As is a non-essential element for plants, also being highly phytotoxic and carcinogenic to humans through the food chain $[3,4]$. As is recognized as one of the most serious inorganic contaminants in natural water worldwide [5].

Mangroves are woody plants that grow on the coastal ecotone in tropical and subtropical latitudes, providing important ecological services including flood protection, prevention of shoreline erosion and salinity buffering [6,7]. Mangrove wetlands serve as both a sink and source for heavy metals (and also metalloids like As) in the coastline ecosystem, which prevents contaminant entry to adjacent waters but could increase the stress to mangrove plants [8,9]. High levels of As were found in mangrove sediments around the world, as $14.0 \mathrm{mg} \cdot \mathrm{kg}^{-1}$ in Xiamen Bay (China) [10], 3.6-18.3 $\mathrm{mg} \cdot \mathrm{kg}^{-1}$ in the Sunderbans mangrove forest (India) [11], up to $70 \mathrm{mg} \cdot \mathrm{kg}^{-1}$ in Espirito Santo (Brazil) [12], 0.52-35 mg $\cdot \mathrm{kg}^{-1}$ in Sydney Estuary (Australia) [13]. Mangrove plants are able to survive under As stress, uptake and enrich As [14]. Recent field studies have shown that As is mainly accumulated in the roots and middle aerial part of Avicennia marina as compared to the upper part [15], As concentrations in fine nutritive roots of Avicennia marina were $\sim 3$-fold higher than those in sediments [13], while the uptake and bioaccumulation of As in Kandelia obovata are also significant [16]. However, field studies cannot provide more useful information on As accumulation and translocation in mangrove plants because of the frequent changes of As concentration and the lack of As concentration gradients in the natural environment. Thus, experimental study with more As concentration gradients, accessible for long-term observation and sampling, is urgently needed.

Aegiceras corniculatum L., an ecologically important tree species with a widespread distribution throughout the estuaries of southern China, was employed to evaluate As accumulation and translocation in mangrove plants. Data of plant growth and arsenic accumulation were collected through pot experiments with As addition to soils. The results of this study will provide useful information to improve our understanding of As tolerance in mangrove plants, and also its accumulation and translocation, and overall potential for As phytoremediation in tropical and subtropical estuarine wetlands.

\section{Experimental Section}

\subsection{Soil Sampling}

Surface soil samples $(0-20 \mathrm{~cm})$ were collected from mangrove sediments at Zhangjiang Estuary $\left(23^{\circ} 55^{\prime} \mathrm{N}, 117^{\circ} 25^{\prime} \mathrm{E}\right.$, Fujian Province, China) for the pot experiments. Basic soil properties of the collected samples were analyzed based on standard methods [17], results are listed in Table 1.

Table 1. Properties of the soil used in the pot experiments. Values are mean $\pm \operatorname{SE}(n=5)$.

\begin{tabular}{cccccc}
\hline $\begin{array}{c}\text { Organic Matter } \\
\mathbf{m g} \cdot \mathbf{k g}^{-\mathbf{1}}\end{array}$ & $\begin{array}{c}\text { Available N } \\
\mathbf{m g} \cdot \mathbf{k g}^{-\mathbf{1}}\end{array}$ & $\begin{array}{c}\text { Available P } \\
\mathbf{m g} \cdot \mathbf{k g}^{-\mathbf{1}}\end{array}$ & $\begin{array}{c}\text { Available K } \\
\mathbf{m g} \cdot \mathbf{k g}^{-\mathbf{1}}\end{array}$ & $\begin{array}{c}\text { Total As } \\
\mathbf{m g} \cdot \mathbf{k g}^{-\mathbf{1}}\end{array}$ & pH \\
\hline $3.17 \pm 0.11$ & $97.85 \pm 4.67$ & $28.41 \pm 1.07$ & $612.59 \pm 18.54$ & $14.32 \pm 0.38$ & $6.63 \pm 0.08$ \\
\hline
\end{tabular}




\subsection{Pot Experiments}

Hypocotyls of $A$. corniculatum collected from the same location were pre-cultured in plastic pots (35 $\mathrm{cm}$ in diameter, $18.5 \mathrm{~cm}$ in-depth) filled with sea sand. The sea sand used was prewashed with concentrated $\mathrm{HCl}$ and rinsed thoroughly with tap water as described by $\mathrm{Du}$ et al. [18]. The pre-cultivation in a half-strength Hoagland's nutrient solution lasted four weeks, and the solution was replaced once a week [19]. The experiment was conducted in a natural light greenhouse, and the salinity of irrigated water was maintained at 12 .

After pre-cultivation, uniformly-sized seedlings were selected. Five seedlings were transplanted to each pot with $\sim 5 \mathrm{~kg}$ either non-contaminated or As contaminated soil (as $\mathrm{Na}_{2} \mathrm{HAsO}_{4} \bullet 7 \mathrm{H}_{2} \mathrm{O}$ ). As concentrations were set based on the baseline concentration of As in the experiment soil (14.32 $\left.\mathrm{mg} \cdot \mathrm{kg}^{-1}\right)$. As treatment concentrations were increased about one-fold or two-fold the baseline As concentration, respectively, resulting in a total of seven treatments $(0,15,30,60,90,120$ or $\left.150 \mathrm{mg} \cdot \mathrm{kg}^{-1} \mathrm{As}\right)$. Each treatment had five replicates. The pot experiments were conducted for 180 days in natural light greenhouses, with a day/night temperature of $33 / 25{ }^{\circ} \mathrm{C}$, and relative humidity of $65 \% / 85 \%$. Plants were watered to maintain soil moisture at $70 \%-80 \%$ of the field water holding capacity by addition of tap water during the experiments.

\subsection{Sampling and Analysis}

At harvest, seedlings were thoroughly washed with distilled water, and the shoot lengths, stem heights and leaf sizes were measured. Seedlings were then separated into root, stem and leaf tissues, and oven dried at $105{ }^{\circ} \mathrm{C}$ for $15 \mathrm{~min}$, then at $70{ }^{\circ} \mathrm{C}$ until the samples reached constant weight. Oven-dried plant tissues were weighed, then ground to powder and passed through 100-mesh sieves.

Precisely $100 \mathrm{mg}$ of plant material was placed into clean digestion tubes for digestion with $1 \mathrm{~mL}$ $\mathrm{HNO}_{3}$ and $\mathrm{H}_{2} \mathrm{O}_{2}(8: 2, \mathrm{v} / \mathrm{v})$ on a heating block at $180{ }^{\circ} \mathrm{C}$ for $1 \mathrm{~h}$, and subsequently at $200{ }^{\circ} \mathrm{C}$ for 45-60 min so as to evaporate the samples to dryness. The residue was taken up in $10 \mathrm{~mL}$ demineralized water. Arsenic concentrations were measured by atomic absorption spectrophotometry (AAS: model AA-6800, Shimadzu, Kyoto, Japan), and calculated by dry weight (DW). Each sample was analyzed three times, and the mean value was calculated. The variances of duplicate measurements were less than 5\%. Results obtained from these analyses were in good agreement with the certified values $( \pm 5 \%)$. The variances of samples in the same pot or in different pots were less than $5 \%$ and $10 \%$, respectively.

The bioconcentration factor (BCF) reflects the ability of plants to accumulate arsenic, and is defined $\mathrm{BCF}=$ Astissue $/ \mathrm{As}_{\text {soil }}$, where Astissues $=$ concentration of As in plant tissues (roots, stems and leaves) and Assoil = concentration of As in soil [16,20,21]. The translocation factor (TF) reflects the ability of plants to translocate As, and is defined $\mathrm{TF}=\mathrm{As}$ aerial/Asroot, where Asaerial $=$ concentration of As in plant's aerial parts (stems and leaves) and Asroot $=$ Concentration of As in roots [22,23].

\subsection{Data Analysis}

Data are presented mean \pm SE of five replicates $(n=5)$. Two-way analysis of variance (ANOVA) was done on all the data to confirm the variability of data and validity of results using SPSS software 
(19.0, SPSS, Inc., Chicago, IL, USA). Duncan's multiple range test (DMRT) was performed to determine the significant difference between treatments at 0.05 probability level.

\section{Results and Discussion}

\subsection{Plant Growth}

The effects of As treatments on A. corniculatum seedling growth after 180 days are shown in Table 2. Treatments of $15-120 \mathrm{mg} \cdot \mathrm{kg}^{-1}$ As had no significant impact on plant growth $(p>0.05)$, but at $150 \mathrm{mg} \cdot \mathrm{kg}^{-1}$ As, root length decreased by $6.04 \%$, stem height by $6.48 \%$ and life size by $18.16 \%$ as compared to the control. Plant biomass also decreased significantly at $150 \mathrm{mg} \cdot \mathrm{kg}^{-1}$ As $(p<0.05)$, with root biomass decreasing by $11.15 \%$, stem biomass by $11.46 \%$, leaf biomass by $20.56 \%$, resulting in the total biomass being decreased by $13.60 \%$ as compared to the control. The toxicity of large doses of heavy metals (e.g., $\mathrm{Cu}, \mathrm{Pb}$ or $\mathrm{Zn}$, or multiple heavy metals) on mangrove plants can cause toxic effects such as reduction in seedling height, leaf area, biomass and root growth, leaf chlorosis or necrosis, to finally induce mortality [24-26]. However, mangrove plants are considered to operate as excluder species for non-essential elements [20,27]. In the present study, A. corniculatum seedlings survived and grew normally at soil treatments of $15-120 \mathrm{mg} \cdot \mathrm{kg}^{-1}$ As without those typical symptoms. These results demonstrated that $A$. corniculatum is an As excluder with the innate capacity to tolerate As stress.

Table 2. Effects of As treatments on $A$. corniculatum seedlings growth. Values are mean \pm $\mathrm{SE}(\mathrm{n}=5)$. Different letters above same columns indicate significant differences at $p<0.05$.

\begin{tabular}{ccccccc}
\hline $\begin{array}{c}\text { As Treatment } \\
\mathbf{m g} \cdot \mathbf{k g}^{-\mathbf{1}}\end{array}$ & $\begin{array}{c}\text { Root Length } \\
\mathbf{~} \mathbf{m}\end{array}$ & $\begin{array}{c}\text { Stem Height } \\
\mathbf{c m}\end{array}$ & $\begin{array}{c}\text { Leaf Size } \\
\mathbf{c m}^{\mathbf{2}}\end{array}$ & $\begin{array}{c}\text { Root Biomass } \\
\mathbf{g ~ D W}\end{array}$ & $\begin{array}{c}\text { Stem Biomass } \\
\mathbf{g ~ D W}\end{array}$ & $\begin{array}{c}\text { Leaf Biomass } \\
\mathbf{g ~ D W}\end{array}$ \\
\hline 0 & $17.05 \pm 0.89^{\mathrm{a}}$ & $14.67 \pm 0.97^{\mathrm{a}}$ & $12.39 \pm 1.17^{\mathrm{a}}$ & $2.03 \pm 0.21^{\mathrm{a}}$ & $3.09 \pm 0.27^{\mathrm{a}}$ & $1.67 \pm 0.17^{\mathrm{a}}$ \\
15 & $16.98 \pm 1.02^{\mathrm{a}}$ & $14.50 \pm 0.89^{\mathrm{a}}$ & $11.97 \pm 1.06^{\mathrm{a}}$ & $2.05 \pm 0.25^{\mathrm{a}}$ & $3.13 \pm 0.31^{\mathrm{a}}$ & $1.68 \pm 0.18^{\mathrm{a}}$ \\
30 & $17.10 \pm 0.98^{\mathrm{a}}$ & $14.70 \pm 1.02^{\mathrm{a}}$ & $11.74 \pm 1.22^{\mathrm{a}}$ & $2.08 \pm 0.31^{\mathrm{a}}$ & $3.14 \pm 0.29^{\mathrm{a}}$ & $1.71 \pm 0.22^{\mathrm{a}}$ \\
60 & $17.07 \pm 0.87^{\mathrm{a}}$ & $14.76 \pm 0.94^{\mathrm{a}}$ & $12.09 \pm 1.04^{\mathrm{a}}$ & $2.07 \pm 0.18^{\mathrm{a}}$ & $3.12 \pm 0.34^{\mathrm{a}}$ & $1.68 \pm 0.15^{\mathrm{a}}$ \\
90 & $16.96 \pm 1.01^{\mathrm{a}}$ & $14.59 \pm 0.87^{\mathrm{a}}$ & $11.95 \pm 1.11^{\mathrm{a}}$ & $2.04 \pm 0.27^{\mathrm{a}}$ & $3.10 \pm 0.37^{\mathrm{a}}$ & $1.64 \pm 0.12^{\mathrm{a}}$ \\
120 & $16.85 \pm 1.06^{\mathrm{a}}$ & $14.43 \pm 1.03^{\mathrm{a}}$ & $11.84 \pm 1.08^{\mathrm{a}}$ & $1.97 \pm 0.29^{\mathrm{a}}$ & $3.06 \pm 0.28^{\mathrm{a}}$ & $1.61 \pm 0.15^{\mathrm{a}}$ \\
150 & $16.02 \pm 0.94^{\mathrm{b}}$ & $13.72 \pm 1.01^{\mathrm{b}}$ & $10.14 \pm 1.21^{\mathrm{b}}$ & $1.81 \pm 0.23^{\mathrm{b}}$ & $2.73 \pm 0.30^{\mathrm{b}}$ & $1.32 \pm 0.14^{\mathrm{b}}$ \\
\hline
\end{tabular}

\subsection{As Accumulation}

As accumulation in A. corniculatum differed with As treatment levels and plant tissues (Figure 1A). As concentrations in roots, stems and leaves were increased by increasing of As treatment concentrations (0-150 mg. $\left.\mathrm{kg}^{-1}\right)$, with significantly linear expression $\left(\mathrm{R}^{2}>0.68, p<0.05\right)$ (Figure $1 \mathrm{~B}$ ). As mainly accumulated in roots $\left(30.29-294.85 \mathrm{mg} \cdot \mathrm{kg}^{-1} \mathrm{DW}\right)$, at levels which were 4.77-13.20-fold higher than those in stems, and 34.23-127.64-fold higher than those in leaves at soil As concentrations of $0-150 \mathrm{mg} \cdot \mathrm{kg}^{-1}$. As accumulation rates in roots were $74.54 \%-89.26 \%$ of the total As accumulation (average $82.23 \% \pm 2.06 \%$ ), while those in stems were $23.68 \%-10.23 \%$ (average $16.68 \% \pm 1.88 \%$ ) and in leaves only $1.78 \%-0.51 \%$ (average $1.09 \% \pm 0.18 \%$ ) (Figure 2). An increasing trend of As 
accumulation rates in roots was found in roots with increasing As treatment concentrations, while opposite trends were found in stems and leaves. High As accumulation in roots was observed in other species like rice [28], ferns [29] and the mangrove species Kandelia obovata [16]. Transport of non-essential elements was interpreted by cell wall immobilization and/or sequestering of the epidermal layers [20]. Thus mangrove plants absorb and store non-essential elements in the perennial tissues, especially roots [30]. A. corniculatum root tissues might be a bio-indicator of As in polluted sediments, as As concentrations in roots are reflective of environmental levels.

A

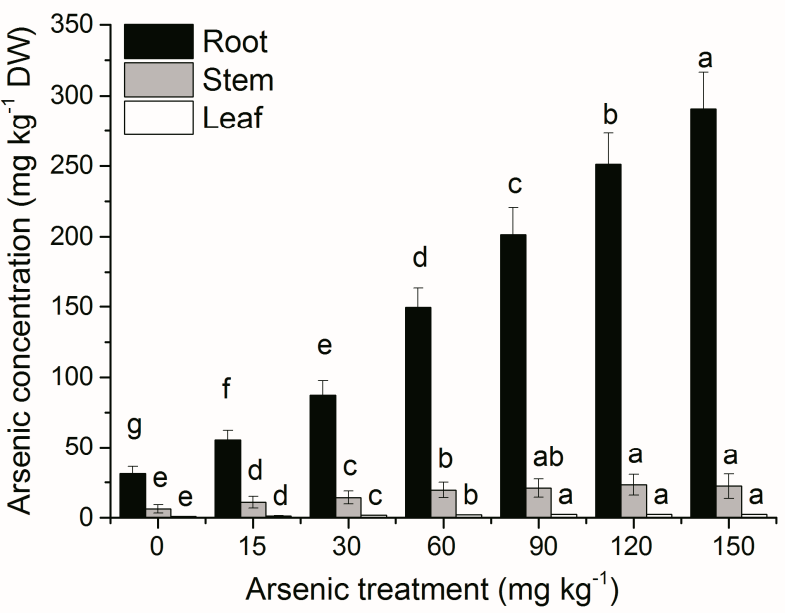

B

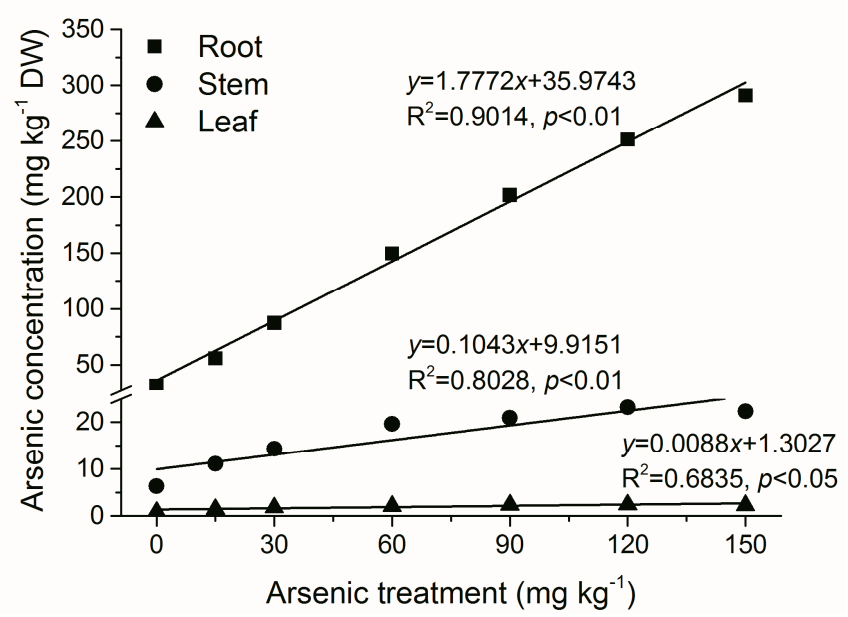

Figure 1. Effects of As treatments on (A) As concentrations in root, stem and leaf, and (B) linear relationship between As treatment concentrations and As concentrations in root, stem and leaf in $A$. corniculatum seedlings. Values are mean $\pm \mathrm{SE}(\mathrm{n}=5)$. Different letters above comparable columns in Figure 1A indicate significant differences at $p<0.05$.

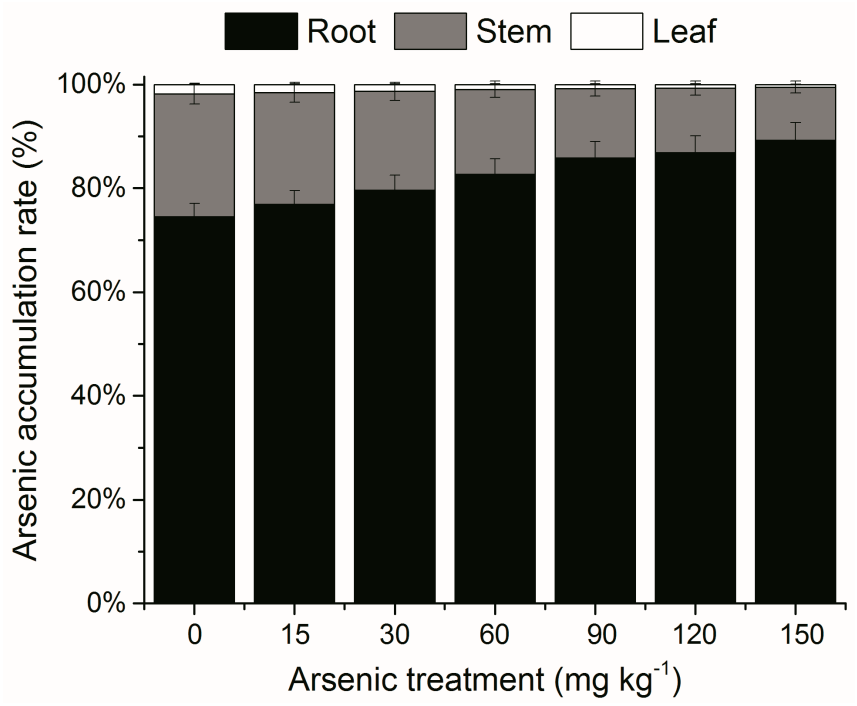

Figure 2. Effects of As treatments on As accumulation rates in root, stem and leaf in A. corniculatum seedlings. Values are mean $\pm \mathrm{SE}(\mathrm{n}=5)$. 


\subsection{Bioconcentration Factor and Translocation Factor}

BCF and TF were further employed to evaluate the ability of $A$. corniculatum to accumulate and translocate As. At treatments of $15-120 \mathrm{mg} \cdot \mathrm{kg}^{-1} \mathrm{As}, \mathrm{BCF}_{\text {root }}$ was reasonable-high (ranged of 2.12-1.79), but $\mathrm{BCF}_{\text {stem }}(0.44-0.14)$ and $\mathrm{BCF}_{\text {leaf }}(0.06-0.01)$ were low, with values at $150 \mathrm{mg} \cdot \mathrm{kg}^{-1}$ As decreased by $15.18 \%, 69.29 \%$ and $77.25 \%$ as compared to the control, respectively (Figure $3 \mathrm{~A}$ ). Meanwhile, $\mathrm{TF}_{\text {stem/root }}(0.21-0.08)$ and $\mathrm{TF}_{\text {leaf } / \text { root }}(0.02-0.008)$ were also extremely low, and values at $150 \mathrm{mg} \cdot \mathrm{kg}^{-1}$ As decreased by $63.80 \%$ and $73.18 \%$ as compared to the control, respectively (Figure 3B). Significant negative correlations were found between TF or BCF values and soil As concentrations $\left(\mathrm{R}^{2}>0.89\right.$,

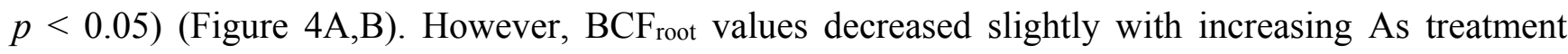
concentrations $\left(0-150 \mathrm{mg} \cdot \mathrm{kg}^{-1}\right)$, while $\mathrm{BCF}_{\text {stem }}$ and $\mathrm{BCF}_{\text {leaf }}$ decreased sharply, resulting in great

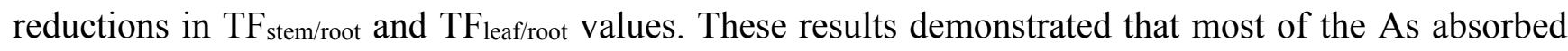
from the soil was retained in the roots and only small amounts were transported to the stems and leaves. Mangroves with high $\mathrm{BCF}_{\text {root }}$ (e.g., Kandelia obovata [16], Avicennia marina [13,31], Phragmites australis [32]) are appropriate candidates for phytostabilisation, retaining metallic inputs and thereby reducing transport to adjacent estuarine and marine systems. Besides, it was suggested that plant species with high $\mathrm{BCF}_{\text {root }}(>1)$ and low TFs $(<1)$ could be considered as a potential candidate for the phytostabilization [33,34]. In the present study, high $\mathrm{BCF}_{\text {root }}(>1)$ and low $\mathrm{TFs}(<1)$ were observed at high soil As concentrations, suggesting that A. corniculatum is a potential candidate mangrove species for As phytostabilization in tropical and subtropical estuarine wetlands.

A

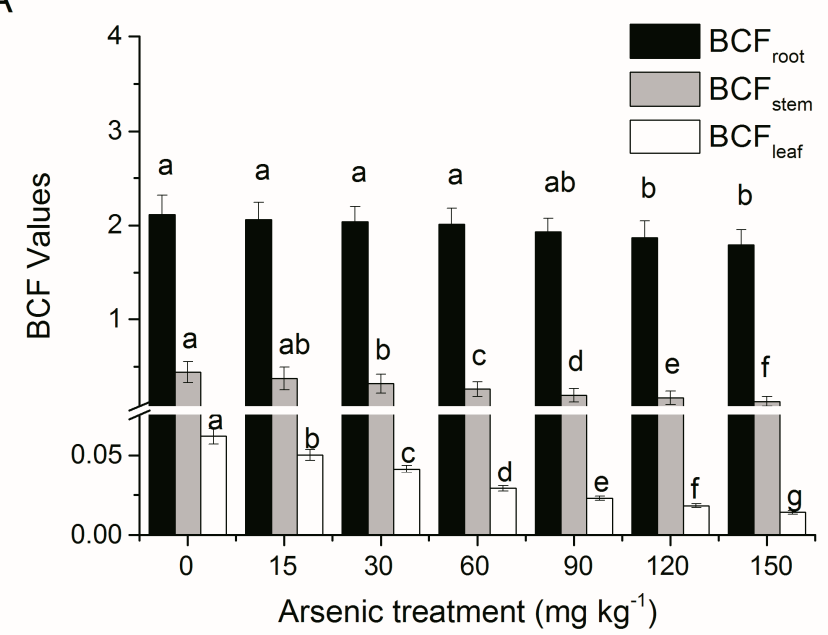

B

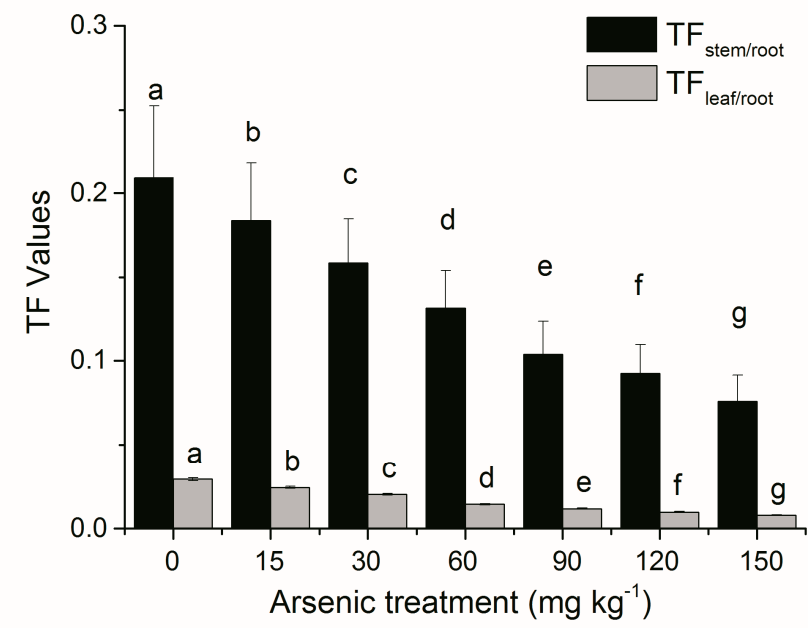

Figure 3. Effects of As treatments on (A) bioconcentration factor (BCF) of root, stem and leaf, and (B) translocation factor (TF) from root to stem and leaf in A. corniculatum seedlings. Values are mean $\pm \mathrm{SE}(\mathrm{n}=5)$. Different letters above comparable columns indicate significant differences at $p<0.05$. 
A

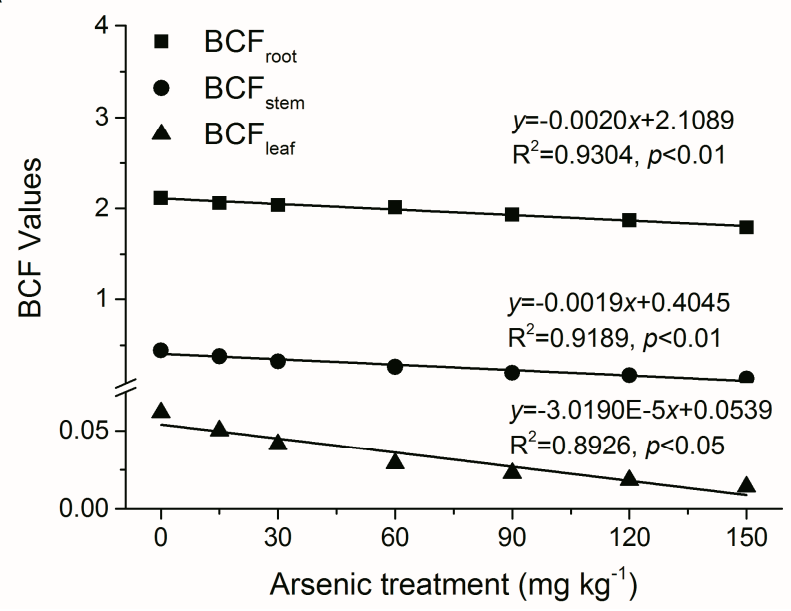

B

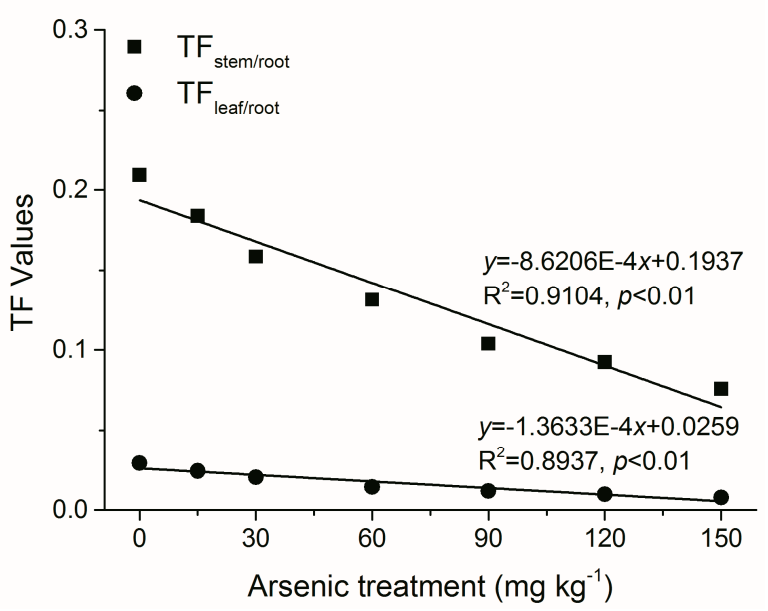

Figure 4. Linear relationship between As treatment concentrations and (A) bioconcentration factor (BCF) of root, stem and leaf, and (B) translocation factor (TF) from root to stem and root to leaf in A. corniculatum seedlings. Values are mean $\pm \mathrm{SE}(\mathrm{n}=5)$.

\section{Conclusions}

In the present study, A. corniculatum seedlings survived and grew normally without typical symptoms of As toxicity, demonstrating that A. corniculatum is an As excluder with an innate capacity to tolerate As stress. As was mainly accumulated in roots, with As concentrations increasing with increasing As treatment concentration, indicating that $A$. corniculatum root tissues may be employed as a bio-indicator of As in polluted sediments. Additionally, relatively high $\mathrm{BCF}_{\text {root }}(>1)$ and low TFs $(<1)$ suggested that $A$. corniculatum is a potential candidate mangrove species for As phyto-stabilization in tropical and subtropical estuarine wetlands.

\section{Acknowledgments}

This work was jointly supported by the National Natural Important Scientific Research Program of China (2013CB956504) and National Natural Science Foundation of China (No. 31370516, 31170471). The authors would like to thank Dou Y.Y. for assistance in sample culture and John Merefield for English grammar.

\section{Author Contributions}

Gui-Rong Wu conceived the study idea, designed the experiments, analyzed the data, and wrote the manuscript. Hua-Long Hong finished a part of the experiments, analyzed the data. Chong-Ling Yan co-conceived the study idea and critically revised the manuscript.

\section{Conflicts of Interest}

The authors declare no conflict of interest. 


\section{References}

1. Mandal, B.K.; Suzuki, K.T. Arsenic round the world: A review. Talanta 2002, 58, 201-235.

2. Bissen, M.; Frimmel, F.H. Arsenic-A review. Part I: Occurrence, toxicity, speciation, mobility. Acta Hydrochim. Hydrobiol. 2003, 31, 9-18.

3. Naujokas, M.F.; Anderson, B.; Ahsan, H.; Aposhian, H.V.; Graziano, J.; Thompson, C.; Suk, W.A. The broad scope of health effects from chronic arsenic exposure: Update on a worldwide public health problem. Environ. Health Perspect. 2013, 121, 295-302.

4. Zhao, F.J.; McGrath, S.P.; Meharg, A.A. Arsenic as a food chain contaminant: Mechanisms of plant uptake and metabolism and mitigation strategies. Ann. Rev. Plant Biol. 2010, 61, 535-559.

5. Tuzen, M.; Citak, D.; Mendil, D.; Soylak, M. Arsenic speciation in natural water samples by coprecipitation-hydride generation atomic absorption spectrometry combination. Talanta 2009, $78,52-56$.

6. Giri, C.; Ochieng, E.; Tieszen, L.L.; Zhu, Z.; Singh, A.; Loveland, T.; Masek, J.; Duke, N. Status and distribution of mangrove forests of the world using earth observation satellite data. Glob. Ecol. Biogeogr. 2011, 20, 154-159.

7. Lee, S.Y.; Primavera, J.H.; Dahdouh-Guebas, F.; McKee, K.; Bosire, J.O.; Cannicci, S.; Diele, K.; Fromard, F.; Koedam, N.; Marchand, C. Ecological role and services of tropical mangrove ecosystems: A reassessment. Glob. Ecol. Biogeogr. 2014, 23, 726-743.

8. Lewis, M.; Pryor, R.; Wilking, L. Fate and effects of anthropogenic chemicals in mangrove ecosystems: A review. Environ. Pollut. 2011, 159, 2328-2346.

9. He, B.; Li, R.L.; Chai, M.W.; Qiu, G.Y. Threat of heavy metal contamination in eight mangrove plants from the Futian mangrove forest, China. Environ. Geochem. Health 2014, 36, 467-476.

10. Vane, C.H.; Harrison, I.; Kim, A.; Moss-Hayes, V.; Vickers, B.; Hong, K. Organic and metal contamination in surface mangrove sediments of South China. Mar. Pollut. Bull. 2009, 58, 134-144.

11. Chatterjee, M.; Massolo, S.; Sarkar, S.K.; Bhattacharya, A.K.; Bhattacharya, B.D.; Satpathy, K.K.; Saha, S. An assessment of trace element contamination in intertidal sediment cores of Sunderban mangrove wetland, India for evaluating sediment quality guidelines. Environ. Monit. Assess. 2009, 150, 307-322.

12. Mirlean, N.; Medeanic, S.; Garcia, F.; Travassos, M.P.; Baisch, P. Arsenic enrichment in shelf and coastal sediment of the Brazilian subtropics. Cont. Shelf Res. 2012, 35, 129-136.

13. Chaudhuri, P.; Nath, B.; Birch, G. Accumulation of trace metals in grey mangrove Avicennia marina fine nutritive roots: The role of rhizosphere processes. Mar. Pollut. Bull. 2014, 79, 284-292.

14. Kirby, J.; Maher, W.; Chariton, A.; Krikowa, F. Arsenic concentrations and speciation in a temperate mangrove ecosystem, NSW, Australia. Appl. Organomet. Chem. 2002, 16, 192-201.

15. Parveen, R.; Zahir, E.; Siddiqui, A.F. Arsenic enrichment in mangroves, and sediments along Karachi coast. J. Coast. Life Med. 2013, 1, 59-64.

16. Liu, C.W.; Chen, Y.Y.; Kao, Y.H.; Maji, S.K. Bioaccumulation and translocation of arsenic in the ecosystem of the Guandu Wetland, Taiwan. Wetlands 2014, 34, 129-140. 
17. Lu, R. Chemistry Analysis Methods of Soil and Agriculture; Agricultural Science Publishing House: Beijing, China, 1999.

18. Du, J.N.; Yan, C.L.; Li, Z.D. Formation of iron plaque on mangrove Kandalar. Obovata (SL) root surfaces and its role in cadmium uptake and translocation. Mar. Pollut. Bull. 2013, 74, 105-109.

19. Hoagland, D.R.; Arnon, D.I. The water-culture method for growing plants without soil. Circ. Calif. Agric. Exp. Stn. 1950, 347, 32.

20. MacFarlane, G.R.; Koller, C.E.; Blomberg, S.P. Accumulation and partitioning of heavy metals in mangroves: A synthesis of field-based studies. Chemosphere 2007, 69, 1454-1464.

21. Baker, A.; Brooks, R. Terrestrial higher plants which hyperaccumulate metallic elements. A review of their distribution, ecology and phytochemistry. Biorecovery 1989, 1, 81-126.

22. Marchiol, L.; Assolari, S.; Sacco, P.; Zerbi, G. Phytoextraction of heavy metals by canola (Brassica napus) and radish (Raphanus sativus) grown on multicontaminated soil. Environ. Pollut. 2004, 132, 21-27.

23. Wang, X.; Ma, L.Q.; Rathinasabapathi, B.; Liu, Y.; Zeng, G. Uptake and translocation of arsenite and arsenate by Pteris vittata L.: Effects of silicon, boron and mercury. Environ. Exp. Bot. 2010, $68,222-229$.

24. MacFarlane, G.R.; Burchett, M.D. Toxicity, growth and accumulation relationships of copper, lead and zinc in the grey mangrove Avicennia marina (Forsk.) Vierh. Mar. Environ. Res. 2002, $54,65-84$.

25. Huang, G.Y.; Wang, Y.S. Physiological and biochemical responses in the leaves of two mangrove plant seedlings (Kandelia candel and Bruguiera gymnorrhiza) exposed to multiple heavy metals. J. Hazard. Mat. 2010, 182, 848-854.

26. MacFarlane, G.; Burchett, M. Photosynthetic pigments and peroxidase activity as indicators of heavy metal stress in the grey mangrove, Avicennia marina (Forsk.) Vierh. Mar. Pollut. Bull. 2001, 42, 233-240.

27. Bayen, S. Occurrence, bioavailability and toxic effects of trace metals and organic contaminants in mangrove ecosystems: A review. Environ. Int. 2012, 48, 84-101.

28. Lei, M.; Tie, B.Q.; Zeng, M.; Qing, P.F.; Song, Z.G.; Williams, P.N.; Huang, Y.Z. An arsenic-contaminated field trial to assess the uptake and translocation of arsenic by genotypes of rice. Environ. Geochem. Health 2013, 35, 379-390.

29. Feng, R.W.; Wang, X.L.; Wei, C.Y.; Tu, S.X. The accumulation and subcellular distribution of arsenic and antimony in four fern plants. Int. J. Phytoremediation 2015, 17, 348-354.

30. Zhou, Y.W.; Peng, Y.S.; Li, X.L.; Chen, G.Z. Accumulation and partitioning of heavy metals in mangrove rhizosphere sediments. Environ. Earth Sci. 2011, 64, 799-807.

31. MacFarlane, G.R.; Pulkownik, A.; Burchett, M.D. Accumulation and distribution of heavy metals in the grey mangrove, Avicennia marina (Forsk.) Vierh.: Biological indication potential. Environ. Pollut. 2003, 123, 139-151.

32. Weis, J.S.; Weis, P. Metal uptake, transport and release by wetland plants: Implications for phytoremediation and restoration. Environ. Int. 2004, 30, 685-700.

33. Yoon, J.; Cao, X.D.; Zhou, Q.X.; Ma, L.Q. Accumulation of Pb, Cu, and $\mathrm{Zn}$ in native plants growing on a contaminated Florida site. Sci. Total Environ. 2006, 368, 456-464. 
34. Meng, L.; Guo, Q.; Mao, P.; Tian, X. Accumulation and tolerance characteristics of zinc in Agropyron cristatum plants exposed to zinc-contaminated soil. Bull. Environ. Contam. Toxicol. 2013, 91, 298-301.

(C) 2015 by the authors; licensee MDPI, Basel, Switzerland. This article is an open access article distributed under the terms and conditions of the Creative Commons Attribution license (http://creativecommons.org/licenses/by/4.0/). 